\title{
Rancang Bangun Sistem Informasi Rekam Jejak Dosen Berbasis WEB (Studi Kasus : Fakultas Teknik Universitas Asahan)
}

\author{
Adi Widarma ${ }^{1}$, Mutia Rahmawan ${ }^{2}$ \\ ${ }^{1,2,3}$ Fakultas Teknik Jurusan Teknik Informatika Universitas Asahan \\ Jl. Jend Ahmad Yani Kisaran Sumatera Utara \\ 'adiwidarmaloegmail.com, ${ }^{2}$ mutiarahmawanegmail.com
}

\begin{abstract}
Abstrak - Aplikasi sistem informasi rekam jejak dosen berbasis web pada Fakultas Teknik Universitas Asahan yang telah dirancang berfungsi sebagai suatu informasi yang bertujuan untuk tempat media penyimpanan data-data untuk melakukan kenaikan jabatan fungsional dosen. Dengan adanya aplikasi ini, Sehingga Fakultas Teknik Universitas Asahan dalam melakukan monitoring atau menyamakan data dan memiliki perekapan/perekaman seluruh data-data penting dosen dalam melakukan kenaikan jabatan. Berdasarkan landasan teori serta analisis pemprograman yang digunakan dengan bahasa pemprograman PHP dengan editor Notepad++ dan database menggunakan XAMPP, sehingga menghasilkan sebuah program rekam jejak dosen yang bertujuan sebagai alat sistem informasi penyimpanan data dosen bagi kenaikan jabatan fungsional yang berbasis web dan aplikasi ini digunakan secara online pada Fakultas Teknik Universitas Asahan.
\end{abstract}

Kata Kunci - Rekam Jejak Dosen, Sistem Informasi, WEB.

\section{PENDAHULUAN}

Perkembangan teknologi informasi berjalan dengan amat pesat. Internet menjadi salah satu kebutuhan yang mutlak bagi pengguna teknologi sekarang ini. Dalam perkembangannya internet merupakan hasil dari teknologi komputerisasi yang dapat berfungsi sebagai sumber informasi yang cepat. Website sebagai media yang digunakan untuk memberikan informasi dan begitu banyak website yang ada didunia ini terhubung dengan internet. Semakin berkembangnya teknologi, maka semakin mudah kita menggunakannya dan mengaplikasikannya untuk kebutuhan sehari-hari.

Universitas Asahan merupakan salah satu institusi perguruan tinggi yang terletak di Kisaran Sumatera Utara. Universitas Asahan mempunyai beberapa fakultas salah satunya adalah Fakultas Teknik. Untuk menunjang sistem informasi yang merupakan suatu unsur yang sangat penting dalam proses pelayanan dimana informasi akan mempengaruhi pelayanan nantinya. Pada sistem informasi ini tempat media penyimpanan data-

data untuk melakukan kenaikan jabatan fungsional dosen selama ini hanya ada pada biro rektor. Sehingga Fakultas Teknik Universitas Asahan dalam melakukan monitoring atau menyamakan data tidak memiliki perekapan/perekaman seluruh data-data penting dosen dalam melakukan kenaikan jabatan.

Dari latar belakang tersebut maka dibutuhkan media sebagai penyimpanan monitoring data atau perekapan/perekaman seluruh data-data penting dosen guna memudahkan dosen untuk melakukan kenaikan jabatan fungsional dan seluruh data-data penting dosen nantinya akan tersimpan didalam sebuah sistem informasi. Dari uraian diatas penelitian ini dapat diambil judul "Rancang Bangun Sistem Informasi Rekam Jejak Dosen Tetap Fakultas Teknik Universitas Asahan Berbasis Web".

\section{LANDASAN TEORI}

\section{A. Rancang Bangun}

Menurut Usep usman Shophani dan Sarmidi (2018), Pengertian rancang bangun merupakan kegiatan menerjemahkan hasil analisa ke dalam bentuk paket perangkat lunak kemudian menciptakan sistem tersebut ataupun memperbaiki sistem yang sudah ada.

Rancang bangun adalah sebuah desain baru untuk mengembangkan sistem yang telah ada ataupun untuk menciptakan sebuah sistem baru yang merupakan kegiatan hasil dari analisa.

\section{$B$. Informasi}

Informasi merupakan data atau fakta yang diproses sedemikian rupa, sehingga berubah bentuknya menjadi informasi. Menurut Rosmila, Dkk (2016), informasi dapat berguna bagi pemakainya atau bisa juga tidak berguna sama sekali. Hal ini tergantung pada kualitas informasi yang dihasilkan, informasi akan berguna apabila kualitasnya baik. Baik buruknya kualitas informasi dipengaruhi oleh tiga faktor yaitu isi informasi, waktu penyajian dan bentuk informasi. Informasi adalah data yang telah diolah menjadi bentuk bermakna dan berguna bagi manusia. Informasi dapat juga diartikan menjadi data yang telah diproses sedemikian rupa sehingga meningkatkan pengetahuan seseorang yang menggunakannya.

Informasi adalah data. Data adalah kenyataan yang menggambarkan suatu kejadian yang akan menjadi suatu informasi, yang mana data tersebut akan diolah dan diterapkan dalam suatu sistem menjadi input yang berguna.

\section{Sistem Informasi}

Menurut Khairullah, Dkk. (2017), Sistem informasi adalah suatu sistem di dalam suatu organisasi yang mempertemukan kebutuhan pengolahan transaksi harian yang mendukung fungsi operasi organisasi yang bersifat manajerial dengan kegiatan strategi dari suatu organisasi untuk dapat 
menyediakan kepada pihak luar tertentu dengan laporan-laporan yang diperlukan.

Manfaat adanya sistem informasi dalam suatu instansi yaitu:

1. Menyajikan informasi guna mendukung pengambilan suatu keputusan.

2. Menyajikan informasi guna mendukung operasi harian.

3. Menyajikan informasi yang berkenaan dengan kepengurusan.

Sistem informasi adalah suatu sistem yang mempertemukan kebutuhan dalam pengolahan yang yang bersifat manjerial untuk dapat menyediakan laporan-laporan yang diperlukan.

\section{Perguruan Tinggi}

Menurut Anak Agung Gde Agung, Dkk. (2014), Perguruan tinggi adalah lembaga yang menyelenggarakan pendidikan tinggi yang mencakup program pendidikan diploma, sarjana, magister, spesialis, dan doktor. Perguruan tinggi berkewajiban menyelenggarakan pendidikan, penelitian, dan pengabdian kepada masyarakat.

Perguruan tinggi ialah suatu pendidikan tinggi yang mencakup program-program pendidikan diantaranya diploma, sarjana, magister, spesialis dan doktor dalam sebuah lembaga pendidikan perguruan tinggi yang berbentuk universitas, institut, sekolah tinggi, politeknik dan akademi.

\section{E. Dosen}

Menurut Prof Dede (dalam Christian Tonyjanto, Dkk. 2017) semua mahasiswa yang memutuskan untuk ambil studi di perguruan tinggi, pasti memiliki angan-angan besar dalam dirinya untuk menjadi seseorang yang berbeda dengan mereka yang putus sekolah pada jenjang menengah atau jenjang pendidikan dasar. Sebahagian dari para mahasiswa mungkin ada yang memiliki idealisme untuk menjadi ilmuwan, dan terus menempuh studi pada jenjang strata satu, dua dan tiga, sehingga menjadi seorang ilmwan bergelar akademik Doktor, atau paling tidak bergelar akademik Master. Akan tetapi, pada umumnya mereka berangan-angan untuk menjadi profesional dan dapat mengakses kesempatan kerja sebagai profesional, diterima kerja sebagai profesional, dan memperoleh penghasilan yang layak sebagai seorang profesional. Untuk itu, mereka harus terlahir sebagai sarjana yang cerdas dan berdaya saing. Angan-angan tersebut, dimiliki oleh hampir semua mahasiswa. Oleh sebab itu, ketika membaca brosur dan informasi program studi, mereka akan mencermati profile dari program studi tersebut serta nama-nama dosen pengampu mata kuliah pada program studi yang mereka minati itu. Program studi paling besar jumlah Guru Besar, atau Doktornya, dan memiliki captive market yang bagus, pasti akan memperoleh peminat paling besar dari seluruh calon mahasiswa. Jika tidak terpenuhi ketiga-tiganya, maka akan secara gradual turun pada dua kriteria, sampai hanya pada satu kriteria saja.

Dosen ialah suatu pengajar atau pendidik profesional yang memiliki kewajiban untuk mengajar para peserta didik yang dilakukan untuk menambah pengetahuan, pengalaman dan memperbaiki moral para peserta didiknya atau mahasiswanya.

\section{F. Web}

Menurut Tatag Abiyoso Utomo, dkk. (2017), web dioperasikan melalui sebuah Web Server. Fungsi dari Web Server adalah untuk mentransfer atau memindahkan berkas yang diminta oleh pengguna melalui protokol komunikasi tertentu. Oleh karena dalam satu halaman web biasanya terdiri dari berbagai macam jenis berkas seperti gambar, video, teks, audio, file dan lain sebagainya, maka pemanfaatan Web Server berfungsi juga untuk mentransfer keseluruhan aspek pemberkasan dalam halaman tersebut, termasuk teks, gambar, video, audio, file dan sebagainya. Perincian komponen Web sebagai berikut :

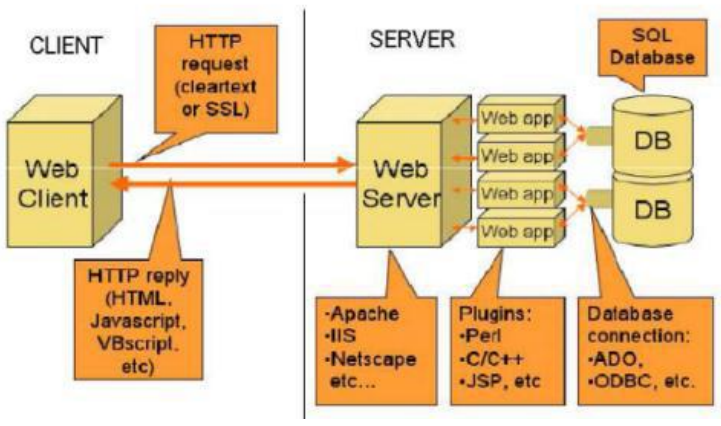

Gambar 1 Komponen Web Secara Detail

Web berkerja dengan cara :

1. Pertama saat user telah membuka web browser seperti google chrome, internet explorer, opera, Mozilla, safari, dll. User akan memasukkan alamat URL yang dituju.

2. Setelah melakukan input, alamat URL yang dituju tersebut akan diterjemahkan menjadi Internet Protokol oleh DNS.

3. Setelah user mengeklik enter maka server akan menerima request dari user ataupun client.

4. Kemudian permintaanya akan diproses

5. Setelah diproses maka munculah web yang user atau client tersebut inginkan.

Web ialah sebuah perangkat lunak yang diakses melalui sebuah internet yang berfungsi untuk dapat memberikan pelayanan kepada user dalam sebuah aplikasi.

\section{G. PHP}

PHP (Hypertext Preprocessor) adalah bahasa script yang dapat dipakai untuk membuat program situs web dinamis. PHP adalah bahasa pemprograman script server-side yang didesain untuk mengembangkan web. Disebut bahasa pemprograman 
server side karena PHP diproses pada komputer server. Hal ini berbeda dibandingkan dengan bahasa pemrograman client-side seperti JavaScript yang diproses pada web browser (client). (Madcoms. 2016:2)

PHP ialah bahasa pemprograman yang digunakan dalam sebuah aplikasi yang berbasis web.

\section{H. Database}

Menurut Ade Hendini (2016:107), Database adalah sekumpulan tabel- tabel yang saling berelasi, relasi tersebut bisa ditunjukkan dengan kunci dari tiap tabel yang ada. Satu database menunjukkan satu lingkup perusahaan atau instansi. Database juga merupakan kumpulan data yang umumnya menggambarkan aktifitas-aktifitas dan pelakunya dalam suatu organisasi. Sistem database merupakan sistem komputer yang digunakan untuk menyimpan dan mengelola data tersebut.

Database adalah sekumpulan data-data dalam penambahan, pengakssesan dan pemprosesan data tersebut dan tersimpan dalam database komputer.

I. Pemodelan Berorientasi Objek Menggunakan Unified Modeling Language (UML)

Menurut Windu Gata (dalam Ade Hendini, 2016), unified modeling language (UML) adalah bahasa spesifikasi standar yang dipergunakan untuk mendokumentasikan, menspesifikasikan dan membanngun perangkat lunak.UML merupakan metodologi dalam mengembangkan sistem berorientasi objek dan juga merupakan alat untuk mendukung pengembangan sistem. Alat bantu yang digunakan dalam perancangan berorientasi objek berbasiskan UML adalah sebagai berikut:

\section{Use Case Diagram}

Use case diagram merupakan pemodelan untuk kelakuan (behavior) sistem informasi yang akan dibuat. Use case digunakan untuk mengetahui fungsi apa saja yang ada di dalam sistem informasi dan siapa saja yang berhak menggunakan fungsi-fungsi tersebut.

2. Diagram Aktivitas (Activity Diagram)

Activity Diagram menggambarkan workflow (aliran kerja) atau aktivitas dari sebuah sistem atau proses bisnis. Simbol-simbol yang digunakan dalam activity Diagram yaitu:

3. Diagram Urutan (Sequence Diagram)

Sequence Diagram menggambarkan kelakuan objek pada use case dengan mendeskripsikan waktu hidup objek dan pesan yang dikirimkan dan diterima antar objek.

4. Diagram Kelas (Class Diagram)

Diagram Kelas (Class Diagram) merupakan hubungan antar kelas dan penjelasan detail tiaptiap kelas di dalam model desain dari suatu sistem, juga memperlihatkan aturan-aturan dan tanggung jawab entitas yang menentukan perilaku sistem.

5. Collaboration Diagram
Diagram ini bersifat dinamis.Diagram kolaborasi adalah diagram interaksi yang menekankan organisasi struktural dari objek-objek yang menerima serta mengirim pesan (message).

6. Diagram Komponen (Component Diagram)

Component diagram menggambarkan struktur fisik dari kode, pemetaan pandangan logis dari kelas proyek untuk kode aktual di mana logika ini dilaksanakan.

7. Deployment Diagram

Deployment diagram memberikan gambaran dari arsitektur fisik perangkat lunak, perangkat keras, dan artefak dari sistem. Deployment diagram dapat dianggap sebagai ujung spektrum dari kasus penggunaan, menggambarkan bentuk fisik dari sistem yang bertentangan dengan gambar konseptual dari pengguna dan perangkat berinteraksi dengan sistem.

8. Statemachine diagram

Statemachine diagram menggambarkan state, transisi state dan event.

\section{METODE PENELITIAN}

\section{A. Rancangan Penelitian}

Rancangan penelitian yang dilakukan dalam penyusunan penelitian ini adalah, mempelajari materi yang berkaitan dengan rancangan penelitian yang meliputi kerangka kerja sebagai berikut :

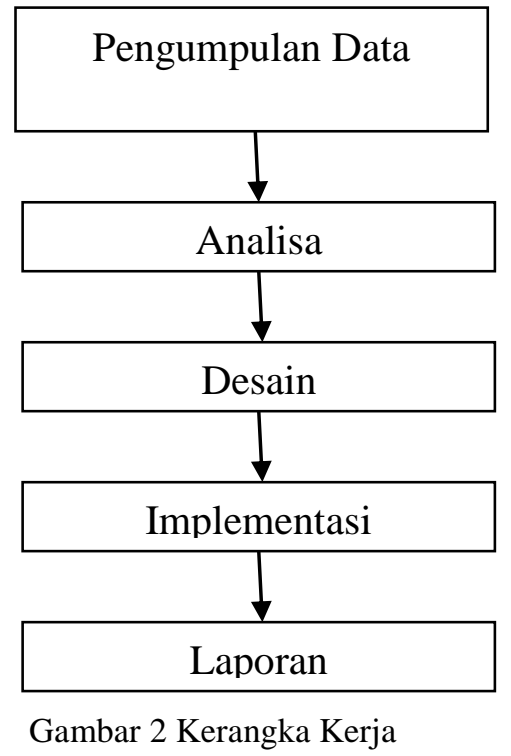

\section{B. Metode Penelitian}

Dalam pembuatan aplikasi ini, metode yang peneliti gunakan berupa metode observasi, yang nantinya digunakan untuk memperoleh data-data yang dibutuhkan dalam pembuatan aplikasi. Metode observasi ini berupa pengumpulan data dari sumbersumber yang berkaitan dengan aplikasi rekam jejak dosen tetap pada Fakultas Teknik Universitas Asahan, antara lain seperti kenaikan jabatan fungsional dosen, dimana diperlukan pencatatan atau perekaman secara fisik guna memudahkan dosen dalam melakukan kenaikan jabatan fungsional dosen. 


\section{Objek Penelitian}

Objek penelitian merupakan permasalahan yang diteliti. Objek penelitian dilakukan pada Fakultas Teknik Universitas Asahan .

\section{Teknik Pengumpulan Data}

Pada bab ini akan dijelaskan tentang sumber dan teknik pengumpulan data yang diperoleh peneliti dalam penyusunan penelitian.

1. Data Primer

Data primer yang diperoleh secara langsung dari data-data dosen tetap pada Fakultas Teknik Universitas Asahan.

2. Data Sekunder

Data sekunder diperlukan untuk mendukung hasil penelitian. Data tersebut berasal dari jurnal, internet dan berbagai sumber lain yang berhubungan dengan masalah penelitian sehingga memudahkan dalam penyelesaian masalah.

\section{E. Metode Analisa Data}

Metode analisa data adalah menganalisis data yang berhasil dikumpul untuk mencapai suatu kesimpulan. Analisa data digunakan untuk suatu sistem informasi secara nyata dan bertujuan untuk melakukan identifikasi terhadap masalah yang muncul dan dapat memberikan solusi yang jelas untuk perbaikan ataupun pengembangan dari suatu sistem.

\section{ANALISA DAN PEMBAHASAN}

\section{A. Analisa Masalah}

Dalam proses analisa masalah ini ditemukan kendala-kendala yang terjadi dalam proses pengajuan jabatan fungsional dosen. Selama ini difakultas teknik masih menggunakan cara manual atau langsung kebagian pihak kepegawai universitas. Hal ini berdampak kurang efektif sehingga harus dibuat sistem yang dapat diintegrasikan kedalam bagian yang sudah ada.

\section{B. Analisa Input}

Dalam proses analisa input ini dapat diberikan yaitu proses input data pengajuan kepangkatan oleh dosen yang bekerja di universitas asahan.

\section{Analisa Proses}

Dalam analisa proses ini merupakan hasil proses yang diolah oleh admin untuk mendata atau menseleksi dokumen dalam proses pengajuan kenaikan pangkat agar dapat diverfikasi oleh admin sehingga dapat memperoleh hasil.

\section{Analisa Output}

Dalam analisa output ini merupakan hasil akhir yang diberikan dari input dan proses sehingga memberikan hasil output berupa hasil laporan data kenaikan pangkat.

\section{E. Perancangan Sistem}

1. Use Case Diagram

Perancangan model dengan use case diagram menggambarkan perilaku sistem yang dibuat. Dalam sistem ini yang peneliti buat, terdapat 2

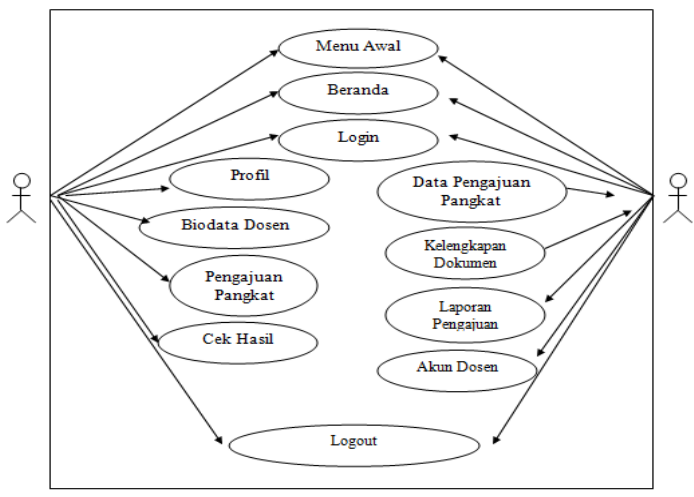

Gambar 3 Use Case

2. Activity Diagram

Perancangan Activity Diagram mengambarkan bagaimana alur aktivitas yang terjadi antara admin atau user didalam sebuah sistem. Agar lebih jelas berikut di bawah ini gambaran Activity Diagram admin.

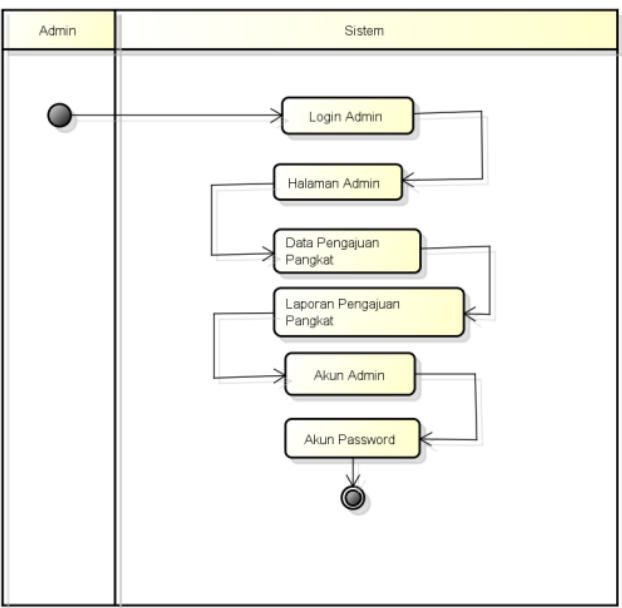

Gambar 4 Activity Diagram

\section{Class Diagram}

Dari perancangan diagram akan dapat diketahui bagaimana hubungan antara tabel didalam database dan proses input apa saja yang ada didalamnya. Untuk gambar dapat dilihat dibawah ini. 


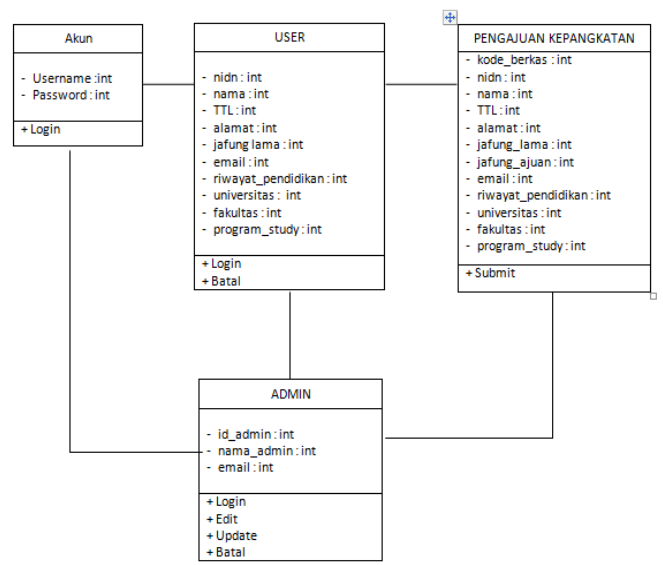

Gambar 5 Class Diagram

\section{Sequence Diagram}

Dari perancangan diagram akan dapat diketahui bagaimana hubungan user dalam sistem dan proses apa saja yang ada didalamnya. Untuk gambar dapat dilihat dibawah ini.

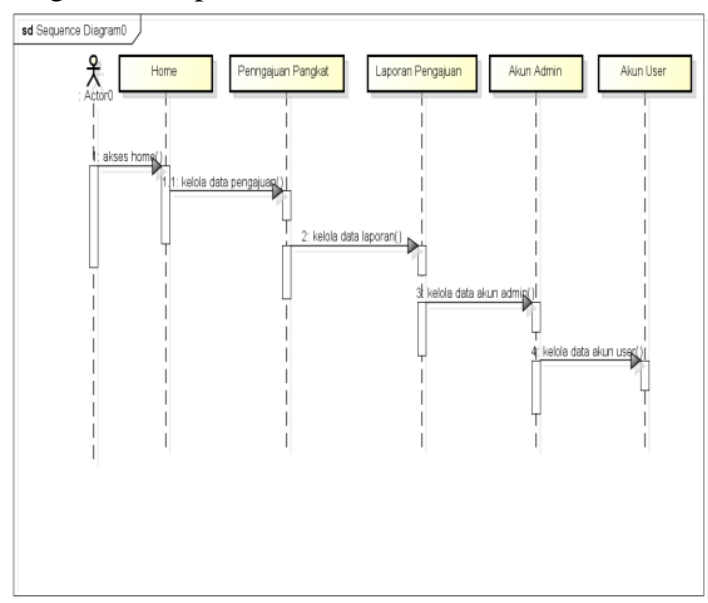

Gambar 6 Sequence Diagram

5. Statemachine Diagram

Statemachine diagram yaitu salah satu jenis diagram pada UML yang menggambarkan transisi maupun perubahan keadaan suatu objek pada sistem. Untuk gambar dapat dilihat dibawah ini.

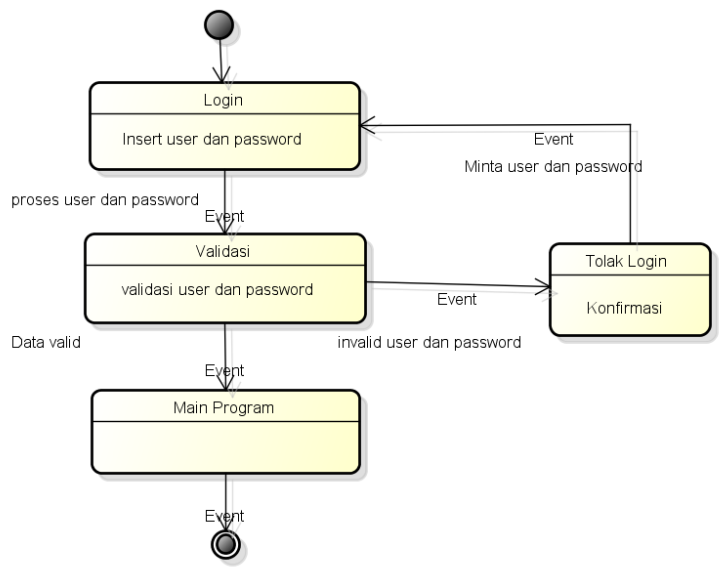

Gambar 7 Statemachine Diagram
6. Communication Diagram

Communication diagram yaitu salah satu jenis diagram pada UML yang dapat menggambarkan tahapan terjadinya suatu aktivitas dan diagram ini juga menggambarkan interaksi antara objek yang ada pada sistem. Hampir sama seperti sequence diagram akan tetapi communication diagram lebih menekankan kepada peranan masing-masing objek pada sistem.

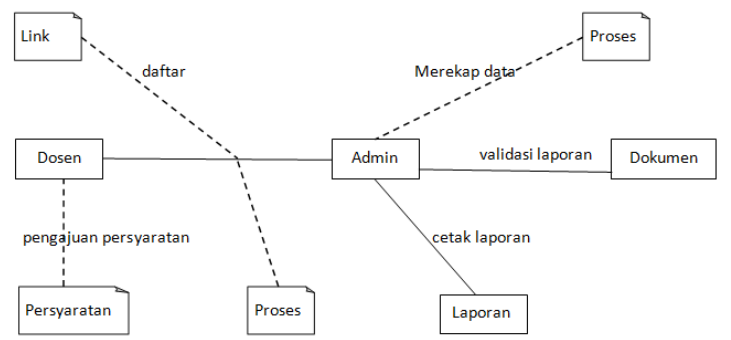

Gambar 8 Communication Diagram

\section{Deployment Diagram}

Deployment diagram yaitu salah satu diagram pada UML yang menunjukan tata letak suatu sistem secara fisik, dapat juga dikatakan untuk menampilkan bagian-bagian software yang terdapat pada hardware dan digunakan untuk menerapkan suatu sistem dan hubungan antara komponen hardware. Jadi Deployment diagram yaitu untuk menunjukan letak software pada hardware yang digunakan sistem.

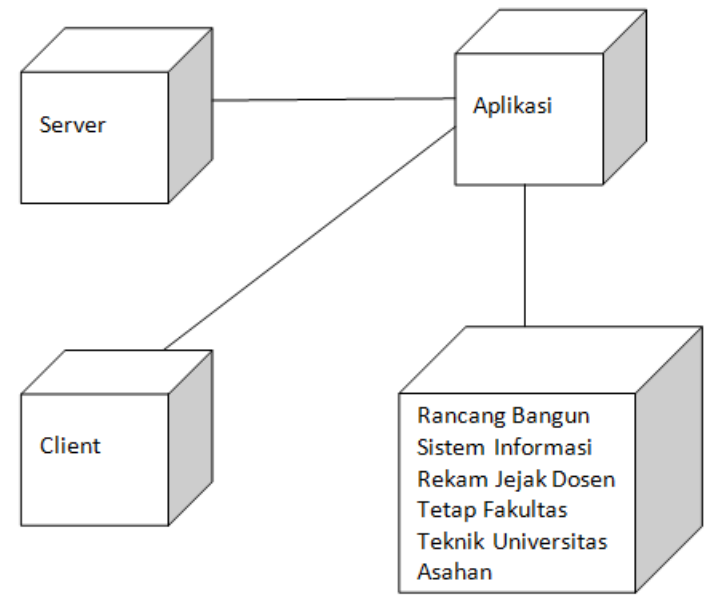

Gambar 9 Deployment Diagram

8. Component Diagram

Component diagram yaitu salah satu jenis diagram pada UML yang menggambarkan software pada suatu sistem. Component diagram merupakan penerapan software dari satu ataupun lebih class, dan biasanya berupa file data atau .exe, source kode, table, dokumen. 


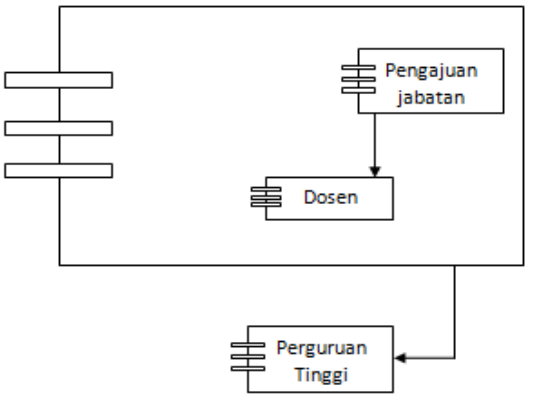

Gambar 10 Component Diagram

\section{F. Implementasi Hasil Rancangan Program}

Implementasi merupakan tahapan pengujian sistem yang dibangun. Adapun hasil implementasi dapat dilihat pada sub bagian dibawah ini.

1. Tampilan Halaman Menu Utama

Tampilan menu utama atau tampilan awal merupakan halaman untuk admin login dan dosen login agar dapat masuk kedalam sistem untuk mengkelola data. Pada tahap ini admin ataupun dosen harus memasukkan user dan password nya dan kemudian login. Adapun gambar dapat dilihat dibawah ini.

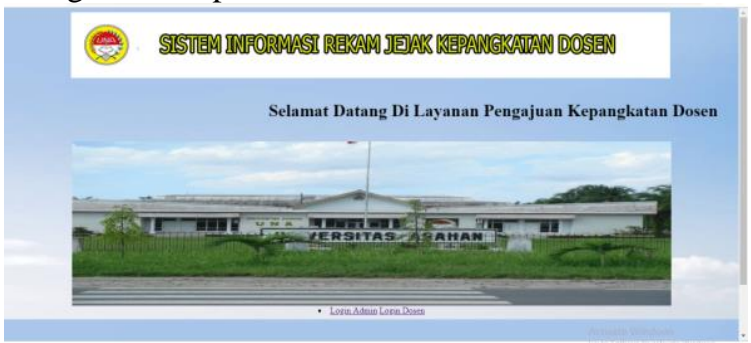

Gambar 11 Tampilan Halaman Utama

2. Tampilan Menu Login Dosen dan Login Admin Pada tampilan halaman ini merupakan input data atau login untuk masuk kehalaman/form berikutnya. Adapun gambarnya dapat dilihat dibawah ini.

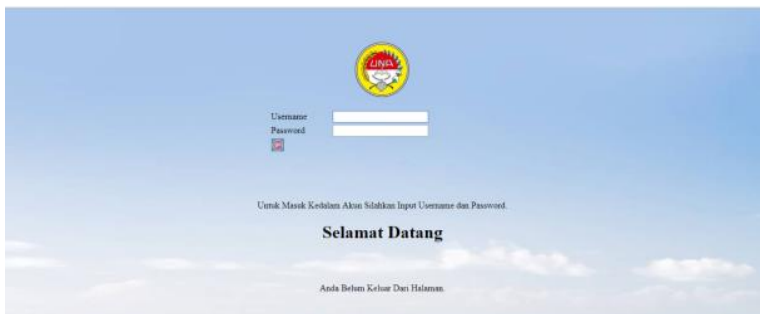

Gambar 12 Tampilan Menu Login Dosen dan Login Admin

3. Tampilan Halaman Utama Admin

Tampilan halaman ini merupakan halaman admin untuk mencek data yang yang telah diinput ke admin. Adapun gambarnya adalah sebagai berikut.

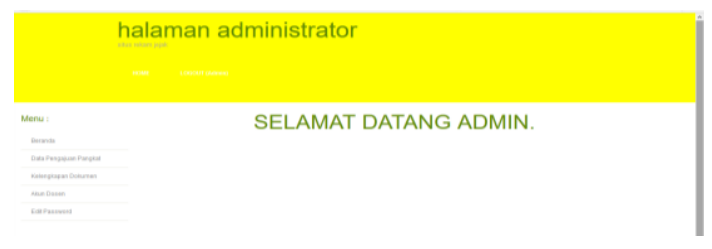

Gambar 13 Tampilan Halaman Admin

4. Tampilan Menu Data Pengajuan

Tampilan halaman ini merupakan halaman untuk melihat data yang telah masuk untuk disetujui admin tentang kelayakan dokumen yang telah dikirim oleh user. Dapat dilihat pada gambar dibawah ini.

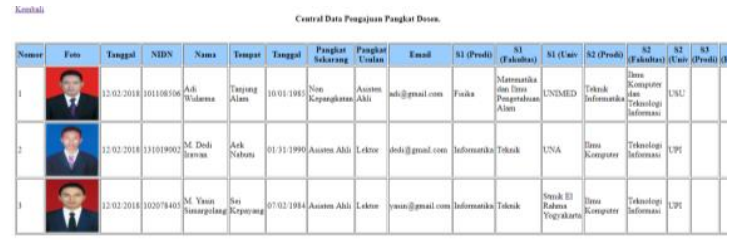

Gambar 14 Tampilan Menu Data Pengajuan

5. Tampilan Menu Edit Akun Admin

Halaman ini merupakan halaman untuk mengedit/merubah password admin. Adapun gambarnya dapat dilihat dibawah ini.

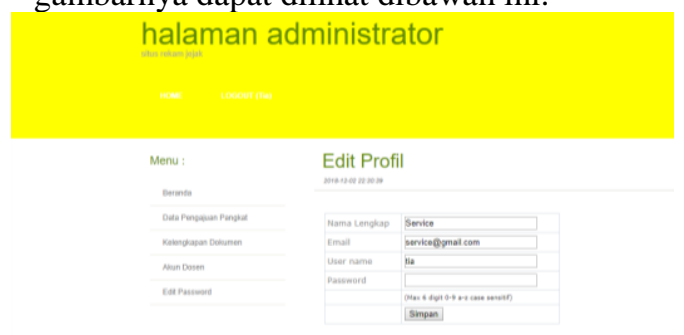

Gambar 15 Tampilan Menu Edit Akun Admin

6. Tampilan Menu Edit Akun Dosen

Pada form ini merupakan halaman untuk menambah akun dosen apabila dosen ingin terdaftar di login dosen sehingga dosen harus terverivikasi terlebih dahulu oleh admin. Pada halaman ini admin tidak hanya dapat menambah login dosen tetapi admin juga dapat mencetak/mengedit username dan password akun user dosen yang telah terdata. Berikut dapat dilihat pada gambar dibawah ini.

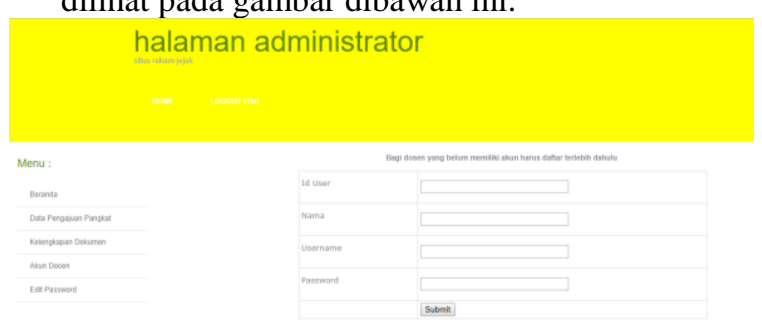

Gambar 16 Tampilan Menu Edit Akun Dosen 
7. Tampilan Halaman Menu Dosen

Halaman ini merupakan halaman dimana terdapat menu untuk menginputkan ataupun mengedit data diri dosen. Adapun gambarnya dapat dilihat sebagai berikut dibawah ini.

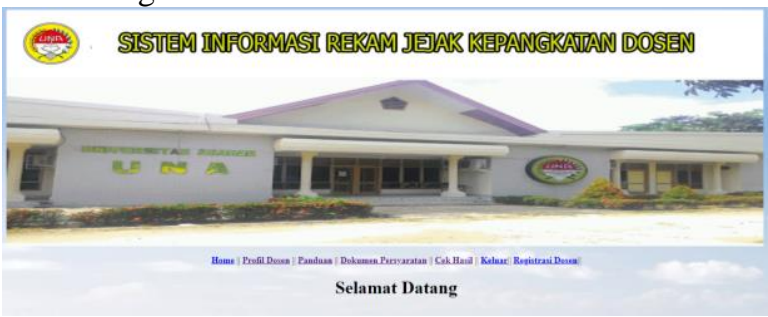

Gambar 17 Tampilan Halaman Menu Dosen

8. Tampilan Halaman Pengajuan Jabatan

Halaman ini merupakan halaman untuk mengupload atau menginputkan dokumen yang dibutuhkan untuk kenaikan jabatan pada dosen yang akan melakukan kenaikan pangkat. Adapun gambarnya dapat dilihat dibawah ini.

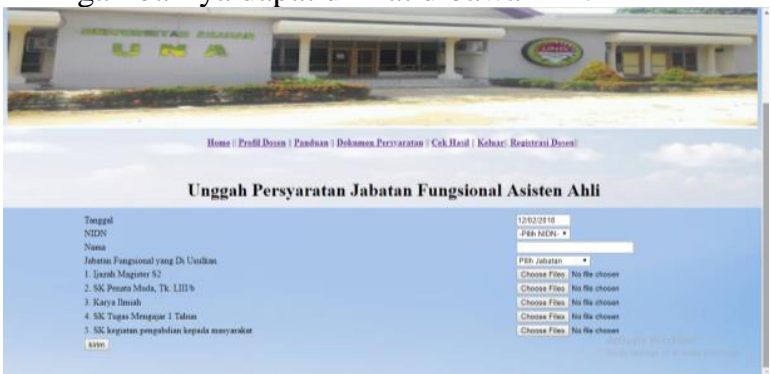

Gambar 18 Tampilan Halaman Pengajuan

9. Tampilan Cetak Hasil Status Pengajuan Jabatan Halaman laporan merupakan halaman untuk mencetak/mencek apakah data yang telah dikirim/diinputkan telah memenuhi persyaratan/kriteria untuk kenaikan jabatan. Adapun gambarnya dapat dilihat dibawah ini.

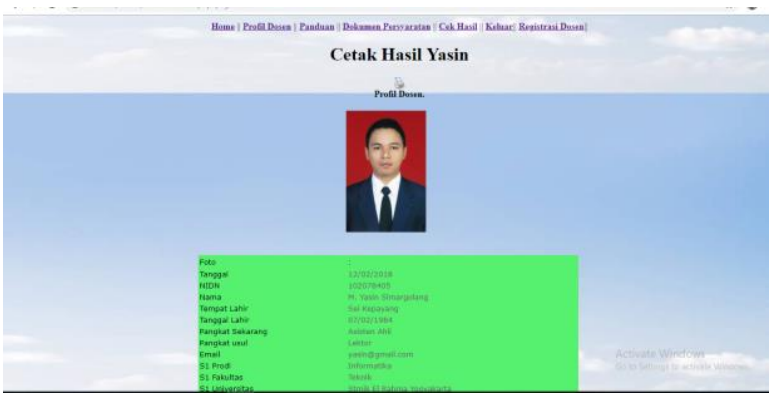

Gambar 19 Tampilan Halaman Cetak Status Pengajuan

\section{PENUTUP}

\section{A. Kesimpulan}

Dari penjelasan yang telah diuraikan dapat ditarik kesimpulan mengenai hal-hal dasar yang sangat erat kaitannya dengan penelitian. Aktifitas yang dilakukan peneliti saat melakukan pengerjaan penelitian ini merupakan hal yang sangat berguna bagi peneliti. Peneliti dapat meneliti proses sistem yang dibangun pada sistem informasi Rekam Jejak Dosen yang ada pada Fakultas Teknik Universitas Asahan berbasis web. Adanya sistem informasi yang telah ada ini maka dosen Fakultas Teknik Universitas Asahan, selain hanya merekam seluruh data-data penting dosen, dosen juga melakukan kenaikan jabatan fungsional dosen.

Dengan telah berakhirnya proses penelitian ini maka peneliti dapat menyimpulkan hasil dari penelitian yang telah didapat dalam suatu laporan, maka peneliti menyimpulkan bahwa :

1. Proses penginputan data yang dilakukan secara online, sehingga untuk mempermudah dosen dalam melakukan kenaikan jabatan.

2. Pada sistem informasi yang telah dirancang dan dibangun ini, user memiliki tempat media penyimpanan data-data dalam proses pengajuan kepangkatan yang akan diusulkan sehingga datadata dapat dilihat secara mudah.

3. Dengan adanya sistem ini sehingga Fakultas Teknik Universitas Asahan, sehingga dosen dapat melakukan monitoring ataupun penyamaan data yang akan tersimpan nantinya didalam sistem informasi ini.

4. Data yang digunakan pada sistem yaitu menggunakan sistem Unified Modelling Language (UML). Dengan menggunakan UML, sehingga pengguna lebih mudah dalam menganalisa dan mendesain suatu sistem.

\section{B. Saran}

Dari pembahasan pada bab-bab sebelumnya berkaitan dengan Rancang Bangun Sistem Informasi Rekam Jejak Dosen Tetap Fakultas Teknik Universitas Asahan Berbasis Web maka peneliti memberikan beberapa saran yang mungkin bisa dijadikan bahan pertimbangan :

1. Disarankan bagi dosen Fakultas Teknik Universitas Asahan untuk pengembangan lebih lanjut dalam proses kegiatan kenaikan jabatan dapat ditambahkan modul penilaian untuk kinerja pada bidang penelitian, pengabdian pada masyarakat serta kegiatan penunjanglainnya. Sehingga proses persyaratan kegiatan kenaikan jabatan dapat terdata secara otomatis.

2. Disarankan agar Fakultas Teknik Universitas Asahan dapat memperbaiki sistem untuk memperlancar pengguna dalam melakukan proses kenaikan jabatan.

3. Disarankan bagi dosen maupun admin Fakultas Teknik Universitas Asahan agar melakukan penginputan dan mengecek data dengan lengkap sesuai dengan peraturan yang telah ditetapkan agar pada saat pemprosesan kenaikan jabatan dapat mempercepat atau memperlancar dan tidak adanya lagi kendala dalam melakukan pengajuan jabatan yang akan diusulkan nantinya. 


\section{DAFTAR PUSTAKA}

[1] Ade Hendini. 2016. Pemodelan UML Sistem Informasi Monitoring Penjualan Dan Stok Barang. Jurnal Khatulistiwa Informatika. Vol. IV. No. 2.

[2] Anak Agung Gde Agung, Dkk. 2014. Desain Indikator Dan Implementasi Penilaian Kinerja Dosen Pada Sistem Informasi. Seminar Nasional Sistem Informasi Indonesia. Vol. 1. No. 1.

[3] Christian Tonyjanto, Dkk. 2017. Perancangan Sistem Informasi Rekam Jejak Dosen Berbasis Web Pada Universitas Dhyana Pura. Jurnal Teknologi Informasi dan Komputer. Vol. 3. No. 1.

[4] Khairullah, Dkk. 2017. Pengukuran Kualitas Sistem Informasi Inventaris Aset Universitas Muhammadiyah Bengkulu Menggunakan Metode MCCALL, Jurnal Informasi Interaktif, Vol. 2. No. 2.

[5] Rosmila, Dkk. 2016. Aplikasi Pembagian Harta Waris Menurut Hukum Islam Dengan Menggunakan Metode Algoritma Genetika, semanTIK, Vol. 2. No. 2.

[6] Tatag Abiyoso Utomo, dkk. 2017. Aplikasi Sistem Informasi Geografis Berbasis Web Dan Android Untuk Pemilihan Jalur Alternatif Menuju Tempat Pariwisata. Jurnal Geodesi Undip. Vol. 6. No. 2.

[7] Tim Madcoms. (2016). Pemprograman PHP dan MySQL Untuk Pemula. Edisi Pertama. Yogyakarta : Andi Offset.

[8] Usep usman Shophani dan Sarmidi. 2018. Rancang Bangun Perangkat Lunak Penilaian Intellegence Quotient (IQ) Dan Emotional Quotient (EQ), JUMANTAKA, Vol. 01. No. 01. 